\title{
Prospective study of dietary inflammatory index and risk of breast cancer in Swedish women
}

\author{
Nitin Shivappa ${ }^{1,2}$, Sven Sandin ${ }^{3}$, Marie Löf ${ }^{4}$, James R Hébert ${ }^{1,2}$, Hans-Olov Adami ${ }^{3,5}$ and Elisabete Weiderpass ${ }^{\star, 3,6,7,8}$ \\ ${ }^{1}$ Cancer Prevention and Control Program, University of South Carolina, Columbia, SC 29208, USA; ${ }^{2}$ Department of Epidemiology \\ and Biostatistics, Arnold School of Public Health, University of South Carolina, Columbia, SC 29208, USA; ${ }^{3}$ Department of Medical \\ Epidemiology and Biostatistics, Karolinska Institutet, PO Box 281, Stockholm 171 77, Sweden; ${ }^{4}$ Department of Biosciences and \\ Nutrition, Karolinska Institutet, Stockholm, Sweden; ${ }^{5}$ Department of Epidemiology, Harvard School of Public Health, Boston, MA \\ 02115, USA; ${ }^{6}$ Department of Research, Cancer Registry of Norway, Oslo, Norway; ${ }^{7}$ Department of Community Medicine, Faculty of \\ Health Sciences, University of Tromsø, The Arctic University of Norway, Tromsø, Norway and ${ }^{8}$ Genetic Epidemiology Group, \\ Folkhälsan Research Center, Helsinki, Finland
}

Background: The role of diet in breast cancer ( $\mathrm{BrCa}$ ) aetiology has been studied widely. Although the results are inconsistent, dietary components have been implicated through their effects on inflammation. We examined the association between a dietary inflammatory index (DII) and BrCa incidence in the Swedish Women's Lifestyle Study.

Methods: The DII was computed at baseline from a validated 80-item food frequency questionnaire in a cohort of 49258 women, among whom 1895 incident $\mathrm{BrCa}$ cases were identified through linkage with the National Cancer Registry through 2011. We used multivariable Cox proportional models to estimate hazard ratios (HR).

Results: Positive associations were observed between $\mathrm{DII}$ and $\mathrm{BrCa}\left(\mathrm{HR}_{\mathrm{DII}}\right.$ quartile 4 vs $1=1.18 ; 95 \% \mathrm{Cl}$ : 1.00, 1.39), with somewhat stronger associations in postmenopausal women ( $\mathrm{HR}_{\mathrm{DII}}$ quartile 4 vs $\left.1=1.22 ; 95 \% \mathrm{Cl}: 1.01,1.46\right)$.

Conclusions: A proinflammatory diet appears to increase the risk of developing $\mathrm{BrCa}$, especially in postmenopausal women.

Breast cancer (BrCa) is the most common cancer in Swedish women, representing $30.3 \%$ of all cancer cases in 2011. Beyond reproductive and hormonal factors (Faupel-Badger et al, 2013) and a few strongly penetrant genes (Dumitrescu and Cotarla, 2005), not much is known with certainty about the causes of BrCa. However, evidence suggests a role for the ability of diet to modulate inflammation in the aetiology of the disease (American Institute for Cancer Research, 2007).

Inflammation is a result of the body's response to tissue insult/injury or to inflammatory stimulants (Keibel et al, 2009; Pan et al, 2009). Chronic inflammation is a known risk factor for several cancers (Philip et al, 2004; Baniyash et al, 2014). Research on the possible effects of diet, inflammation, and cancer occurrence is, however, methodologically challenging (Hebert and Miller, 1988). However, the newly developed dietary inflammatory index (DII) (Shivappa et al, 2014b) has been shown to predict the levels of inflammatory markers
(Shivappa et al, 2014c, 2015b) and cancer outcomes (Shivappa et al, 2015a; 2014a) in diverse populations.

Specific dietary components may influence both inflammation (Galland, 2010) and BrCa risk (Linos and Willett, 2007). Inflammatory cytokines and other factors that regulate inflammation might be associated with $\mathrm{BrCa}$ (Harris et al, 2014) and might modify the effect of hormonal factors that are causally related to $\mathrm{BrCa}$ (Touvier et al, 2013).We therefore examined the association between the DII and $\mathrm{BrCa}$ incidence in the Swedish Women's Lifestyle Health (SWLH) study. Our hypothesis is that a higher DII score (indicating proinflammatory diet) increases the risk of incident $\mathrm{BrCa}$.

\section{SUBJECTS AND METHODS}

Study cohort. Details regarding the SWLH cohort design have been published elsewhere (Kumle et al, 2002). In brief, the cohort

*Correspondence: Professor E Weiderpass; E-mail: Elisabete.weiderpass@ki.se

Received 8 April 2015; revised 17 July 2015; accepted 31 July 2015; published online 3 September 2015

(c) 2015 Cancer Research UK. All rights reserved 0007-0920/15 
consisted of 49258 women who returned a completed comprehensive questionnaire in 1991-1992. Incident breast cancers were obtained through linkage with the National Cancer Register. The SWLH study was approved by the Swedish Data Inspection Board and the Regional Ethical Committee of Uppsala University and Karolinska Institutet. All participants signed an informed consent form.

Dietary inflammatory index. Dietary data were collected using a validated 80 -item food frequency questionnaire (FFQ) completed at baseline. Nutrients were determined using the Swedish National Food Administration database. Developing the DII involved reviewing and scoring nearly 2000 scientific articles representing studies of different design on diet and inflammation. To calculate the DII, dietary data were first linked to the previously described regionally representative world database that provided a mean and standard deviation for each parameter (Shivappa et al, 2014b). These then became the multipliers to express an individual's exposure relative to the 'standard global mean' (from the 11 data sets used for comparative purposes) as a $z$-score. We converted this score to a centred percentile score, which was then multiplied by the respective food parameter effect score, to obtain a food parameter-specific DII score (Shivappa et al, 2014b). All of the food parameter-specific DII scores were then summed to create the overall DII score for every participant. The methodology is depicted in Figure 1. For the current study, data on 29 of the 45

Review of articles published from 1950 to 2010, resulting in 1943 studies linking a total of 45 food parameters with inflammatory biomarkers

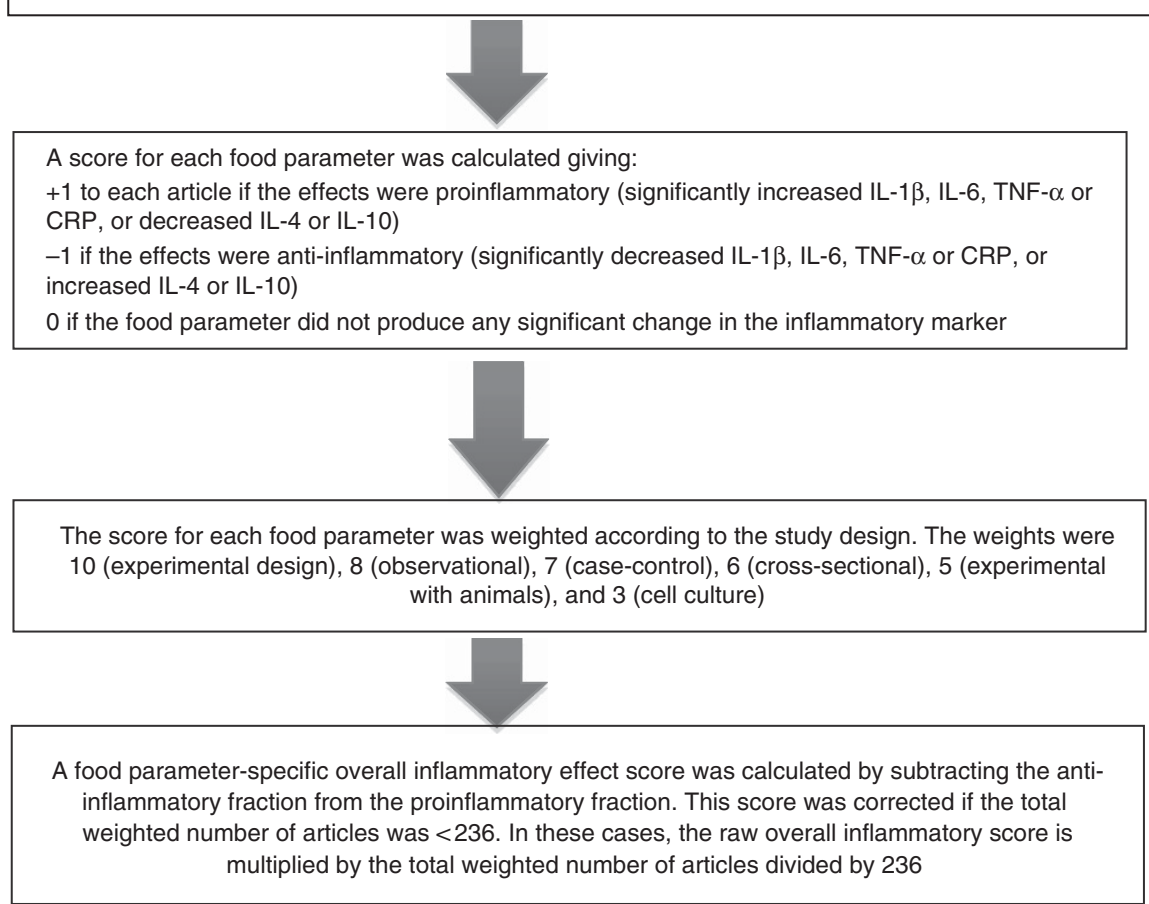

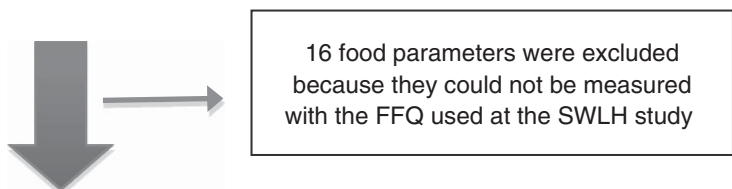

Z-score and centered-percentiles for each of the 29 food parameters ${ }^{*}$ for each participant of this study were calculated based on the average and standard deviation for each food parameter obtained from the global database which was created from the consumption of the original 45 food parameters from 11 countries from around the world

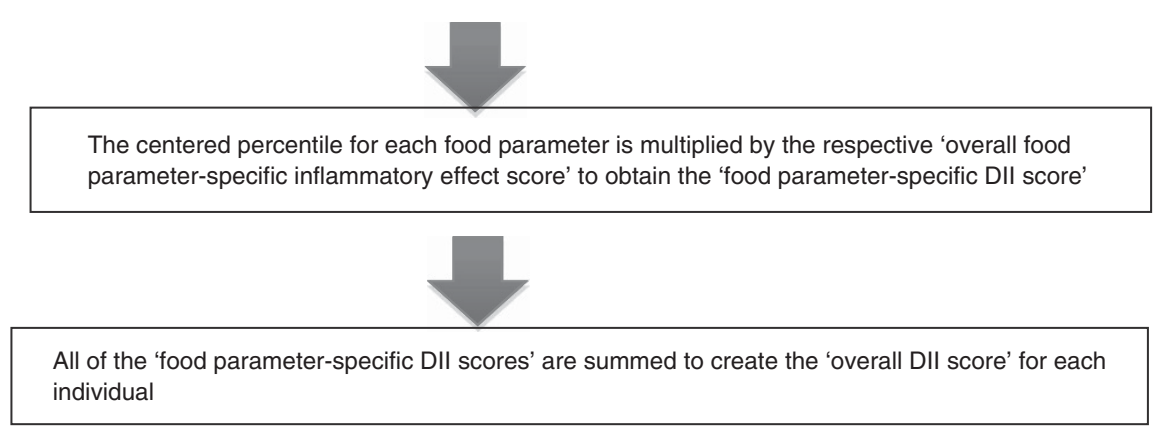

Figure 1. Sequence of steps in creating the dietary inflammatory index in the SWLH study. 
possible food parameters were available for DII calculation (Supplementary Table 1).

Follow-up. The cohort was followed from 1992 until 31 December 2012. Follow-up time was calculated from the date of entry into the cohort until the occurrence of $\mathrm{BrCa}$, emigration, death, or the end of the observation period, whichever came first. A total of 1895 newly diagnosed incident $\mathrm{BrCa}$ cases were identified (International Classification of Diseases, 7 th revision, code 170.0).

We determined age at menopause by combining information from the baseline questionnaire with a follow-up questionnaire conducted in 2002-2003, with responses obtained from 29867 participants. Women without information on age at menopause were considered postmenopausal at 53 years of age (i.e., the 75 th percentile of age at menopause in the study population).

Statistical analyses. Participants were excluded if they had been diagnosed with $\mathrm{BrCa}$ at or before recruitment $(N=244)$, or had extreme energy intake outside the 1st and 99th percentiles $(N=981)$. Study characteristics were examined across DII quartiles (Table 1).

Dietary inflammatory index was analysed both as a continuous variable and as quartiles. Hazard ratios (HRs) and 95\% confidence intervals (CIs) were calculated using Cox proportional hazards regression models, adjusting only for age in Model 1 . Model 2 additionally adjusted for history of $\mathrm{BrCa}$ in a first-degree relative, smoking, BMI, height, age at first birth, total number of children, educational level (years in school), age at menarche, total energy intake, multivitamin use, and oral contraceptive use. The covariates were chosen a priori, as they are established or suggested as risk factors for BrCa. A linear test for trend was conducted using the median approach. The assumption of proportional hazards was tested by adding to the model an interaction term between follow-up time and DII; there was no evidence that these assumptions were violated.

Nearly significant interaction was observed for menopausal status $(P$-value $=0.06)$; hence, the analyses also were stratified by menopausal status. To account for the possibility that a change in dietary pattern occurred since baseline, sensitivity analysis was performed restricting the follow-up to 10 years (1991-2001). Analyses were performed using SAS 9.3 (SAS Institute Inc., Cary, NC, USA); all tests of statistical hypothesis were made on the twosided $5 \%$ level of significance.

\section{RESULTS}

Data from 45257 women were available, with an average follow-up period of 20 years. Mean DII was 2.67 (s.d. $= \pm 1.47$ ). Across

Table 1. Prevalence of characteristics at baseline across quartiles of DII in the SWLH study

\begin{tabular}{|c|c|c|c|c|}
\hline \multirow[b]{2}{*}{$\begin{array}{l}\text { Characteristics }{ }^{\mathrm{b}} \\
\text { (mean (s.d.) or \%) }\end{array}$} & \multicolumn{4}{|c|}{$\mathrm{DII}^{\mathrm{a}}$} \\
\hline & $\begin{array}{c}\text { Quartile } 1<1.87 \\
\text { Median }=1.01 \\
N=11314\end{array}$ & $\begin{array}{c}\text { Quartile } 2 \text { 1.87-2.92 } \\
\text { Median }=2.45 \\
N=11315\end{array}$ & $\begin{array}{c}\text { Quartile } 32.93-3.77 \\
\text { Median }=3.36 \\
N=11313\end{array}$ & $\begin{array}{c}\text { Quartile } 4>3.77 \\
\text { Median }=4.24 \\
N=11315\end{array}$ \\
\hline Breast cancer cases (\%) & $454(4.0)$ & $493(4.4)$ & $468(4.1)$ & $480(4.2)$ \\
\hline \multicolumn{5}{|l|}{ Stage of breast cancer } \\
\hline In situ & $64(14.4)$ & $69(15.1)$ & $69(16.1)$ & $66(14.0)$ \\
\hline Invasive & $390(85.6)$ & $424(84.9)$ & $399(83.9)$ & $414(85.0)$ \\
\hline Age (years) & $40.4(5.7)$ & $40.3(5.7)$ & $40.2(5.7)$ & $40.3(5.8)$ \\
\hline Age at menarche (years) & $12.9(1.4)$ & $12.9(1.3)$ & $13.0(1.3)$ & $13.0(1.3)$ \\
\hline Total energy intake (kcal per day) & $1924(409)$ & $1655(356)$ & $1462(332)$ & $1193(344)$ \\
\hline PUFA (g per day) & $9.6(3.1)$ & $8.1(2.4)$ & $7.1(2.1)$ & $5.7(2.0)$ \\
\hline Dietary fibre (g per day) & $19.6(4.5)$ & $15.0(2.9)$ & $12.4(2.6)$ & $9.4(2.7)$ \\
\hline $\mathrm{BMI}\left(\mathrm{kg} \mathrm{m}^{-2}\right)$ & $23.6(3.7)$ & $23.5(3.7)$ & $23.4(3.6)$ & $23.4(3.7)$ \\
\hline \multicolumn{5}{|l|}{ Education (\%) } \\
\hline Low & 37.4 & 41.4 & 45.9 & 53.0 \\
\hline High & 62.6 & 58.6 & 54.1 & 47.0 \\
\hline \multicolumn{5}{|l|}{ Smoking (\%) } \\
\hline Never & 47.5 & 43.2 & 39.6 & 34.2 \\
\hline Former & 36.9 & 37.4 & 38.1 & 37.4 \\
\hline Current & 15.6 & 19.4 & 22.3 & 28.4 \\
\hline Multivitamin use (\%) & 18.3 & 16.0 & 14.0 & 11.0 \\
\hline Oral contraceptive use (yes) (\%) & 60.4 & 61.0 & 60.9 & 59.3 \\
\hline \multicolumn{5}{|c|}{ Age at first birth (years) and total number of children at baseline } \\
\hline \multicolumn{5}{|c|}{\begin{tabular}{|l|l|l|} 
Parity & &
\end{tabular}} \\
\hline No children & 9.1 & 8.9 & 9.7 & 11.3 \\
\hline$<30,1$ child & 4.4 & 4.9 & 5.2 & 6.3 \\
\hline$<30,2$ children & 25.9 & 28.1 & 29.5 & 26.8 \\
\hline$<30, \geqslant 3$ children & 26.4 & 24.8 & 23.0 & 21.6 \\
\hline$\geqslant 30,1$ child & 7.9 & 7.5 & 8.2 & 9.2 \\
\hline$\geqslant 30,2$ children & 17.2 & 17.4 & 16.4 & 16.5 \\
\hline$\geqslant 30, \geqslant 3$ children & 9.1 & 8.3 & 8.2 & 8.4 \\
\hline \multicolumn{5}{|l|}{ Physical activity (\%) } \\
\hline Sitting only/sedentary & 2.8 & 3.2 & 4.2 & 6.6 \\
\hline Walking only & 65.8 & 69.8 & 72.3 & 73.1 \\
\hline Moderate & 20.2 & 18.3 & 15.5 & 13.9 \\
\hline Vigorous & 11.2 & 8.7 & 7.9 & 6.4 \\
\hline
\end{tabular}


Table 2. DII and breast cancer risk by menopausal status

\begin{tabular}{|c|c|c|c|c|c|c|}
\hline & $\begin{array}{c}\text { Quartile } 1<1.87 \\
\text { Median }=1.01 \\
N=11314\end{array}$ & $\begin{array}{c}\text { Quartile } 2 \text { 1.87-2.92 } \\
\text { Median-2.45 } \\
N=11315\end{array}$ & $\begin{array}{c}\text { Quartile } 32.93-3.77 \\
\text { Median }=3.36 \\
N=11313\end{array}$ & $\begin{array}{c}\text { Quartile } 4>3.77 \\
\text { Median }=4.24 \\
N=11315\end{array}$ & $P$-value ${ }^{a}$ & Dll continuous \\
\hline Cases/person years & $454 / 203583$ & $493 / 204109$ & $468 / 203472$ & $480 / 203050$ & & $1895 / 814214$ \\
\hline \multicolumn{7}{|l|}{ Overall } \\
\hline $\begin{array}{l}\text { Model 1b }(\mathrm{HR}, 95 \% \mathrm{Cl}) \\
\text { Model } 2^{c}(\mathrm{HR}, 95 \% \mathrm{Cl})\end{array}$ & $\begin{array}{l}1^{a} \\
1^{a}\end{array}$ & $\begin{array}{l}1.09(0.96,1.24) \\
1.11(0.97,1.23)\end{array}$ & $\begin{array}{l}1.05(0.93,1.20) \\
1.10(0.95,1.23)\end{array}$ & $\begin{array}{l}1.08(0.95,1.22) \\
1.18(1.00,1.39)\end{array}$ & $\begin{array}{l}0.32 \\
0.07\end{array}$ & $\begin{array}{l}1.02(0.98,1.01) \\
1.04(1.01,1.09)\end{array}$ \\
\hline \multicolumn{7}{|l|}{ Menopausal status } \\
\hline $\begin{array}{l}\text { Pre } \\
\qquad \text { Model } 1^{\mathrm{b}}(\mathrm{HR}, 95 \% \mathrm{Cl}) \\
\text { Model } 2^{\mathrm{c}}(\mathrm{HR}, 95 \% \mathrm{Cl})\end{array}$ & $\begin{array}{l}1^{a} \\
1^{a}\end{array}$ & $\begin{array}{l}0.92(0.69,1.22) \\
0.93(0.70,1.24)\end{array}$ & $\begin{array}{l}0.77(0.56,1.05) \\
0.76(0.55,1.04)\end{array}$ & $\begin{array}{l}0.96(0.68,1.34) \\
0.96(0.68,1.35)\end{array}$ & $\begin{array}{l}0.45 \\
0.43\end{array}$ & $\begin{array}{l}0.94(0.86,1.02) \\
0.93(0.86,1.02)\end{array}$ \\
\hline $\begin{array}{l}\text { Post } \\
\qquad \begin{array}{l}\text { Model } 1^{b}(\mathrm{HR}, 95 \% \mathrm{Cl}) \\
\text { Model } 2^{c}(\mathrm{HR}, 95 \% \mathrm{Cl})\end{array}\end{array}$ & $\begin{array}{l}1^{a} \\
1^{a}\end{array}$ & $\begin{array}{l}1.17(1.00,1.37) \\
1.17(1.00,1.36)\end{array}$ & $\begin{array}{l}1.20(1.02,1.41) \\
1.18(1.00,1.40)\end{array}$ & $\begin{array}{l}1.22(1.02,1.47) \\
1.22(1.02,1.46)\end{array}$ & $\begin{array}{l}0.02 \\
0.03\end{array}$ & $\begin{array}{l}1.07,1.02,1.12 \\
1.07,1.02,1.12\end{array}$ \\
\hline \multicolumn{7}{|c|}{$\begin{array}{l}\text { Abbreviations: } \mathrm{BMI}=\text { body mass index; } \mathrm{Cl}=\text { confidence interval; } \mathrm{DII}=\text { dietary inflammatory index; } \mathrm{HR}=\text { hazard ratio. } \\
\mathrm{a}_{\mathrm{P}} \text {-value for trend determined through the median approach. } \\
{ }^{\mathrm{b}} \text { Model 1: Age-adjusted. } \\
{ }^{\mathrm{c}} \text { Model 2: Adjusted for energy, age at first birth and number of children, age at menarche, BMI, height, multivitamin use, education, smoking status, oral contraceptive use, and family history of } \\
\text { breast cancer in the model. }\end{array}$} \\
\hline
\end{tabular}

increasing DII quartiles, decreasing trends were observed for energy, PUFA, and dietary fibre intake, multivitamin use, higher education, and oral contraceptive use. Increasing trends were observed for current smokers, nulliparous women, and those reporting low levels of physical activity (Table 1).

Multivariable analyses showed positive associations with $\mathrm{BrCa}$ risk both when DII was analysed as a continuous variable $(\mathrm{HR}=1.04 ; 95 \% \mathrm{CI}: 1.00-1.09)$ and in quartiles $\left(\mathrm{HR}_{\mathrm{DII}}\right.$ quartile $4 v \mathrm{~s}_{1}=$ 1.18; 95\% CI: $1.00-1.39, P$-value for trend $=0.07)($ Table 2$)$. When analyses were stratified by menopausal status, DII was associated with breast cancer only among postmenopausal women $\left(\mathrm{HR}_{\mathrm{DII}}\right.$ quartile 4 vs $\left.1=1.22 ; 95 \% \mathrm{CI}: 1.01,1.46\right)$. Sensitivity analysis carried out by restricting the follow-up to 10 years showed similar results $\left(\mathrm{HR}_{\text {continuous }}=1.08\right.$; 95\% CI: 1.01-1.16) (Table 2).

\section{DISCUSSION}

Our prospective study of Swedish women showed evidence of a positive association between a proinflammatory diet and incident $\mathrm{BrCa}$, most convincingly among postmenopausal women. Previous studies on diet and BrCA have shown mixed results. Mediterranean diet and diets composed largely of vegetables, fruit, fish, and soy are associated with a decreased risk (Albuquerque et al, 2014). However, previously the SWLH showed no association with Mediterranean dietary pattern (Couto et al, 2013). This should not be too surprising as a healthy Swedish diet may not adhere to the Mediterranean prescription. In a large European cohort (the EPIC study), saturated fat showed only a marginal association with BrCA risk (Sieri et al, 2008), whereas other studies have found no association (Willett and Hunter, 1994; Park et al, 2012).

Consistent with the results from other studies on diet and $\mathrm{BrCa}$ (Linos and Willett, 2007), we observed a stronger association among postmenopausal women. In the EPIC study, adherence to a Mediterranean score was associated with a modest reduction in the risk of $\mathrm{BrCa}$ in postmenopausal women with no association among premenopausal women (Buckland et al, 2013). In other studies, higher CRP and IL- $1 \beta$ levels increased the risk of developing $\mathrm{BrCa}$ (Onitilo et al, 2012; Pooja et al, 2012). The DII has previously been shown to be positively associated with these cytokines (Shivappa et al, 2014c, 2015b). A positive association of the DII with $\mathrm{BrCa}$ might arise through the effect of proinflammatory diet on increasing systemic inflammation through activation of insulin-like growth factor receptor (Festa et al, 2000; Esmaillzadeh et al, 2007).

Strengths of the present study include its population-based design, large sample size, prospective data collection with extended follow-up and near-complete case ascertainment. One limitation is that DII was calculated just once with an instrument that is prone to measurement error. However, no disease-related information bias was possible because of the prospective study design and adult dietary patterns appear to remain relatively stable over time (Jensen et al, 1984; Jain et al, 1989). Also, a change in dietary pattern since baseline would be expected to dilute an effect of diet. Therefore, the fact that results did not vary much in the sensitivity analysis where we restricted our data to only 10 years of follow-up is prima facie evidence of lack of a biasing effect of time since FFQ data were collected.

Another limitation could be the non-availability of 16 food parameters for DII calculation including some categories of flavonoids, turmeric, thyme, saffron, and others that are usually consumed in small amounts, infrequently, or not consumed at all in the Swedish population; hence, they may not have had a major impact on the scoring. Absence of information on tumor hormone receptor status for the cancer cases, vitamin D status, and body composition status are possible limitations to the study. However, it should be noted that most women in Western populations are receptor positive and the vast majority of postmenopausal women are receptor positive (Palmer et al, 2007; Reis-Filho and Tutt, 2008). Another limitation is the absence of a significant trend for association across quartiles. This could be because of the presence of other factors that could contribute to the incidence of $\mathrm{BrCa}$, with hormonal factors being the most important one.

In conclusion, women who consumed a more proinflammatory diet appear to be at increased risk of breast cancer compared with women who consumed an anti-inflammatory diet, especially in postmenopausal women.

\section{ACKNOWLEDGEMENTS}

This study was supported by National Cancer Institute Grant R01 CA39742. Swedish Women's Lifestyle Health study is supported by grants from the Swedish Research Council (K2012-69X-22062-01-3) and the Swedish Cancer Society. Drs Shivappa and Hébert were supported by R44DK103377 from the United States National Institute of Diabetes and Digestive and Kidney Diseases. 


\section{CONFLICT OF INTEREST}

Dr James R Hébert owns Connecting Health Innovations LLC (CHI), a company planning to develop DII-based computer and smart phone applications for patient counseling and dietary intervention in clinical settings. Dr Nitin Shivappa is an employee of CHI.

\section{REFERENCES}

American Institute for Cancer Research (2007) Food, Nutrition, Physical Activity and the Prevention of Cancer: A Global Perspective. American Institute for Cancer Research: Washington, DC, USA.

Albuquerque RC, Baltar VT, Marchioni DM (2014) Breast cancer and dietary patterns: a systematic review. Nutr Rev 72(1): 1-17.

Baniyash M, Sade-Feldman M, Kanterman J (2014) Chronic inflammation and cancer: suppressing the suppressors. Cancer Immunol Immunother 63(1): 11-20.

Buckland G, Travier N, Cottet V, Gonzalez CA, Lujan-Barroso L, Agudo A, Trichopoulou A, Lagiou P, Trichopoulos D, Peeters PH, May A, Bueno-de-Mesquita HB, Bvan Duijnhoven FJ, Key TJ, Allen N, Khaw KT, Wareham N, Romieu I, McCormack V, Boutron-Ruault M, Clavel-Chapelon F, Panico S, Agnoli C, Palli D, Tumino R, Vineis P, Amiano P, Barricarte A, Rodriguez L, Sanchez MJ, Chirlaque MD, Kaaks R, Teucher B, Boeing H, Bergmann MM, Overvad K, Dahm CC, Tjonneland A, Olsen A, Manjer J, Wirfalt E, Hallmans G, Johansson I, Lund E, Hjartaker A, Skeie G, Vergnaud AC, Norat T, Romaguera D, Riboli E (2013) Adherence to the mediterranean diet and risk of breast cancer in the European prospective investigation into cancer and nutrition cohort study. Int J Cancer 132(12): 2918-2927.

Couto E, Sandin S, Lof M, Ursin G, Adami HO, Weiderpass E (2013) Mediterranean dietary pattern and risk of breast cancer. PLoS One 8(2): e55374.

Dumitrescu RG, Cotarla I (2005) Understanding breast cancer risk - where do we stand in 2005? J Cell Mol Med 9(1): 208-221.

Esmaillzadeh A, Kimiagar M, Mehrabi Y, Azadbakht L, Hu FB, Willett WC (2007) Dietary patterns and markers of systemic inflammation among Iranian women. J Nutr 137(4): 992-998.

Faupel-Badger JM, Arcaro KF, Balkam JJ, Eliassen AH, Hassiotou F, Lebrilla CB, Michels KB, Palmer JR, Schedin P, Stuebe AM, Watson CJ, Sherman ME (2013) Postpartum remodeling, lactation, and breast cancer risk: summary of a National Cancer Institute-sponsored workshop. J Natl Cancer Inst 105(3): 166-174.

Festa A, D’Agostino R, Howard G, Mykkänen L, Tracy RP, Haffner SM (2000) Chronic subclinical inflammation as part of the insulin resistance syndrome: The Insulin Resistance Atherosclerosis Study (IRAS). Circulation 102(1): 42-47.

Galland L (2010) Diet and inflammation. Nutr Clin Pract 25(6): 634-640.

Harris RE, Casto BC, Harris ZM (2014) Cyclooxygenase-2 and the inflammogenesis of breast cancer. World J Clin Oncol 5(4): 677-692.

Hebert JR, Miller DR (1988) Methodologic considerations for investigating the diet-cancer link. Am J Clin Nutr 47(6): 1068-1077.

Jain M, Howe GR, Harrison L, Miller AB (1989) A study of repeatability of dietary data over a seven-year period. Am J Epidemiol 129(2): $422-429$.

Jensen OM, Wahrendorf J, Rosenqvist A, Geser A (1984) The reliability of questionnaire-derived historical dietary information and temporal stability of food habits in individuals. Am J Epidemiol 120(2): 281-290.

Keibel A, Singh V, Sharma MC (2009) Inflammation, microenvironment, and the immune system in cancer progression. Curr Pharm Des 15(17): 1949-1955.

Kumle M, Weiderpass E, Braaten T, Persson I, Adami HO, Lund E (2002) Use of oral contraceptives and breast cancer risk: The Norwegian-Swedish Women's Lifestyle and Health Cohort Study. Cancer Epidemiol Biomarkers Prev 11(11): 1375-1381.
Linos E, Willett WC (2007) Diet and breast cancer risk reduction. J Natl Compr Cancer Netw 5(8): 711-718.

Onitilo AA, Engel JM, Stankowski RV, Liang H, Berg RL, Doi SA (2012) High-sensitivity C-reactive protein (hs-CRP) as a biomarker for trastuzumab-induced cardiotoxicity in HER2-positive early-stage breast cancer: a pilot study. Breast Cancer Res Treat 134(1): 291-298.

Palmer JR, Adams-Campbell LL, Boggs DA, Wise LA, Rosenberg L (2007) A prospective study of body size and breast cancer in black women. Cancer Epidemiol Biomarkers Prev 16(9): 1795-1802.

Pan MH, Lai CS, Dushenkov S, Ho CT (2009) Modulation of inflammatory genes by natural dietary bioactive compounds. J Agric Food Chem 57(11): 4467-4477.

Park SY, Kolonel LN, Henderson BE, Wilkens LR (2012) Dietary fat and breast cancer in postmenopausal women according to ethnicity and hormone receptor status: the Multiethnic Cohort Study. Cancer Prev Res (Phila) 5(2): 216-228.

Philip M, Rowley DA, Schreiber H (2004) Inflammation as a tumor promoter in cancer induction. Semin Cancer Biol 14(6): 433-439.

Pooja S, Chaudhary P, Nayak LV, Rajender S, Saini KS, Deol D, Kumar S, Bid HK, Konwar R (2012) Polymorphic variations in IL-1beta, IL-6 and IL-10 genes, their circulating serum levels and breast cancer risk in Indian women. Cytokine 60(1): 122-128.

Reis-Filho JS, Tutt AN (2008) Triple negative tumours: a critical review. Histopathology 52(1): 108-118.

Shivappa N, Bosetti C, Zucchetto A, Montella M, Serraino D, LaVecchia C, Hébert JR (2015a) Association between dietary inflammatory index and prostate cancer among Italian men. Br J Nutr 113(2): 278-283.

Shivappa N, Hebert JR, Rietzschel ER, De Buyzere ML, Langlois M, Debruyne E, Marcos A, Huybrechts I (2015b) Associations between dietary inflammatory index and inflammatory markers in the Asklepios Study. Br J Nutr 113(4): 665-671.

Shivappa N, Prizment AE, Blair CK, Jacobs DR, Steck SE, Hébert JR (2014a) Dietary inflammatory index and risk of colorectal cancer in the Iowa Women's Health Study. Cancer Epidemiol Biomar 23(11): 2383-2392.

Shivappa N, Steck SE, Hurley TG, Hussey JR, Hebert JR (2014b) Designing and developing a literature-derived, population-based dietary inflammatory index. Public Health Nutr 17(8): 1689-1696.

Shivappa N, Steck SE, Hurley TG, Hussey JR, Ma Y, Ockene IS, Tabung F, Hebert JR (2014c) A population-based dietary inflammatory index predicts levels of C-reactive protein in the Seasonal Variation of Blood Cholesterol Study (SEASONS). Public Health Nutr 17(8): $1825-1833$.

Sieri S, Krogh V, Ferrari P, Berrino F, Pala V, Thiebaut AC, Tjonneland A, Olsen A, Overvad K, Jakobsen MU, Clavel-Chapelon F, Chajes V, Boutron-Ruault MC, Kaaks R, Linseisen J, Boeing H, Nothlings U, Trichopoulou A, Naska A, Lagiou P, Panico S, Palli D, Vineis P, Tumino R, Lund E, Kumle M, Skeie G, Gonzalez CA, Ardanaz E, Amiano P, Tormo MJ, Martinez-Garcia C, Quiros JR, Berglund G, Gullberg B, Hallmans G, Lenner P, Bueno-de-Mesquita HB, van Duijnhoven FJ, Peeters PH, van Gils CH, Key TJ, Crowe FL, Bingham S, Khaw KT, Rinaldi S, Slimani N, Jenab M, Norat T, Riboli E (2008) Dietary fat and breast cancer risk in the European Prospective Investigation into Cancer and Nutrition. Am J Clin Nutr 88(5): 1304-1312.

Touvier M, Fezeu L, Ahluwalia N, Julia C, Charnaux N, Sutton A, Mejean C, Latino-Martel P, Hercberg S, Galan P, Czernichow S (2013) Association between prediagnostic biomarkers of inflammation and endothelial function and cancer risk: a Nested Case-Control Study. Am J Epidemiol 177(1): 3-13.

Willett WC, Hunter DJ (1994) Prospective studies of diet and breast cancer. Cancer 74(Suppl 3): 1085-1089.

This work is published under the standard license to publish agreement. After 12 months the work will become freely available and the license terms will switch to a Creative Commons AttributionNonCommercial-Share Alike 4.0 Unported License.

Supplementary Information accompanies this paper on British Journal of Cancer website (http://www.nature.com/bjc) 